\title{
Chemoprotective effect of Fumaria parviflora $L$. extract against vincristine induced hepatotoxicity in male rats
}

\author{
Zahra Rezaeikia $^{1,2}$, Sakineh Saeidi-Sar ${ }^{3}$, Noorolhoda Malakijoo ${ }^{2,4}, \underline{\text { Zahra Mousavi }}^{5,6}$ \\ ${ }^{I}$ MSc student, Department of Chemistry, Collage of Science, Damghan Branch, Islamic Azad University, Damghan- \\ Iran. \\ 2 Pharmaceutical Research Center, Faculty of Pharmacy and Pharmaceutical Sciences, Tehran Medical Sciences, \\ Islamic Azad University, Tehran-Iran \\ ${ }^{3}$ Department of Chemistry, Collage of Science, Damghan Branch, Islamic Azad University, Damghan-Iran. \\ ${ }^{4}$ MSc Toxicology student, Faculty of Pharmacy and Pharmaceutical Sciences, Tehran Medical Sciences, Islamic Azad \\ University (IAUPS), Tehran, Iran \\ ${ }^{5}$ Department of Pharmacology and Toxicology, Faculty of Pharmacy and Pharmaceutical Sciences, Tehran Medical \\ Sciences, Islamic Azad University (IAUPS), Tehran, Iran \\ ${ }^{6}$ Herbal pharmacological Research Center, Faculty of Medicine, Tehran Medical Sciences, Islamic Azad University, \\ Tehran, Iran
}

\begin{abstract}
Background: Hepatoprotective effects of Fumaria parviflora have been approved in pharmaceutical and chemical toxicity models. Given the importance of the vincristine- induced hepatotoxicity during chemotherapy, the aim of this study was to investigate the potential hepatoprotective effects of $F$. parviflora extract on vincristine induced toxicity in adult male rats.

Materials and methods: In this experimental study, the rats $(n=42)$ were divided into 7 groups: 1) Sham group, 2) vehicle group, 3) vincristine group (VCR) $(0.5 \mathrm{mg} / \mathrm{kg}$, i.p.), 4) F. parviflora extract (300 mg/kg, p.o.), 5) F. parviflora extract (500 mg/kg, p.o.), 6) Pretreatment group: $F$. parviflora extract (300mg/kg for 10 days, p.o. $)+\operatorname{VCR}(0.5 \mathrm{mg} / \mathrm{kg}$, i.p.) on 9th and 10th days of the experiment, and 7) Pretreatment group: $F$. parviflora extract $(500 \mathrm{mg} / \mathrm{kg}$ for 10 days, p.o.) $+\mathrm{VCR}(0.5 \mathrm{mg} / \mathrm{kg}$, i.p. $)$ on 9 th and 10 th days of the experiment. Serum values of AST, ALT, ALP and malondialdehyde (MDA) were measured. Data were analyzed by one way ANOVA using prism software.

Results: F. parviflora extract with dose of $500 \mathrm{mg} / \mathrm{kg}$ markedly decreased ALT hepatic enzyme level caused by vincristine $(\mathrm{P}<0.01)$. In addition, the dose of $300 \mathrm{mg} / \mathrm{kg}$ could not decrease the elevated liver enzymes, including ALP, ALT and AST and also MDA levels.

Conclusion: Hepatoprotective effects of $F$. parviflora extract were not considerable in pretreatment groups. Keywords: F. parviflora, vincristine, Hepatotoxicity, Rat.

Cited as: Rezaeikia Z, Saeidi-Sar S, Malakijoo N, Mousavi Z. Evaluation of chemoprotective effect of Fumaria parviflora L. extract against vincristine induced hepatotoxicity in male rats. Medical Science Journal of Islamic Azad University, Tehran Medical Branch 2019; 29(2): 125-130.
\end{abstract}

Correspondence to: Zahra Mousavi

Tel: +989125081304

E-mail: mosavi50@ hotmail.com

ORCID ID: 0000-0001-6524-491X

Received: 6 Aug 2018; Accepted: 22 Oct 2018 
مجله علوم يزشكى دانشعاه آزاد اسلامى

\section{Fumaria ( بررسى اثر محافظتى (ييشگيرانه) عصاره هيدروالكلى گياه شاهتره كَل ريز (parviflora L.}

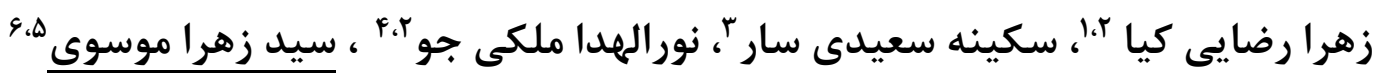

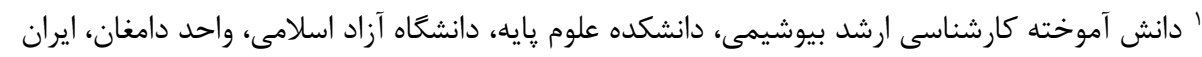

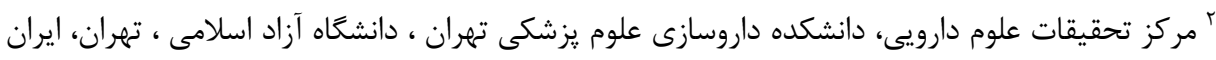

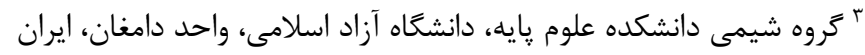

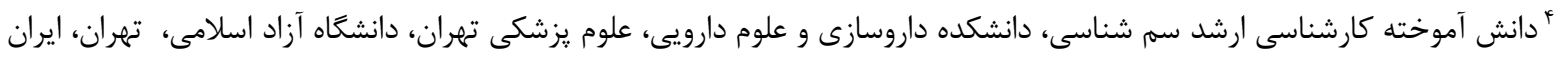

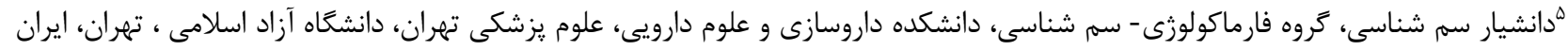

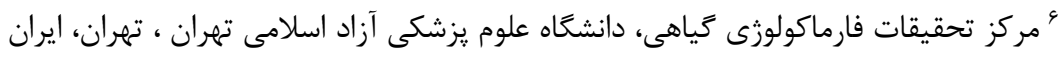

جـكبده سابقه و هدف: اثرات حفاظت كبدى كياه شاهتره در مدل هاى سميت ناشى /ز مواد شيميايى و دارويى به اثبات رسيده /ست. با توجه

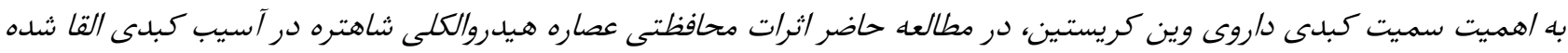

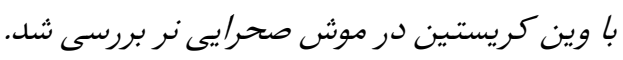

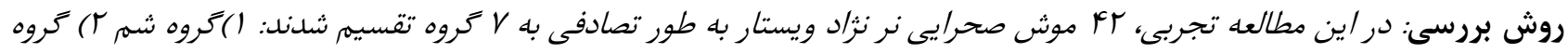

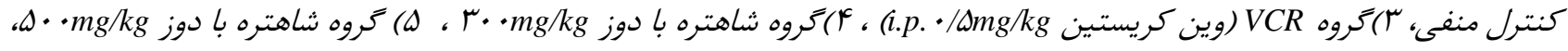
و) كروه بيشَيرى: شاهتره

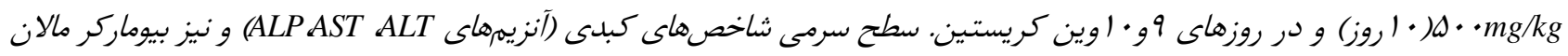
دى آلدئيد اندازه كيرى شد. نتايج توسط نرم افزار يريسم و آزمون يافتها: شاهتره با دوز

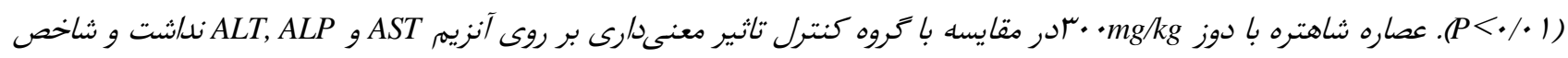
اكسيداتيو MDA همجنان بالا بود.

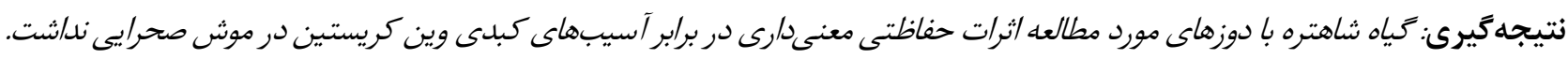

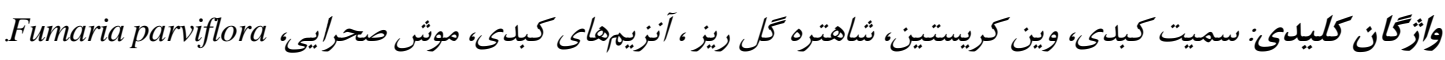

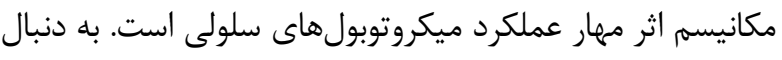

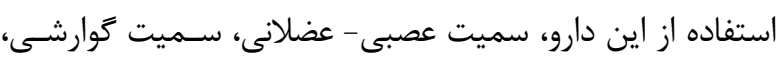

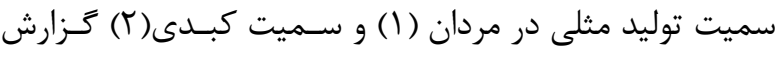

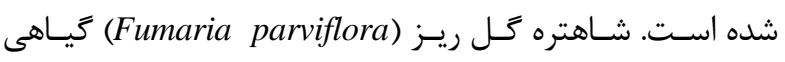

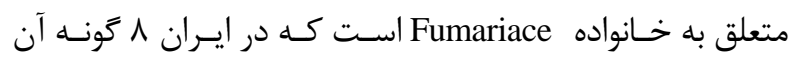

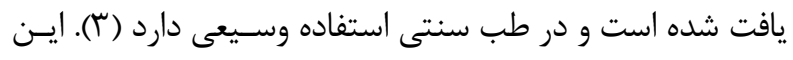

سرطان به عنوان يكى از بزركترين و يرخطرترين بيمـارىهـاى

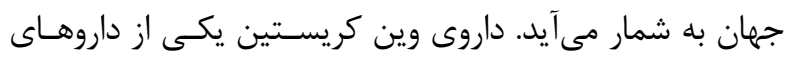

آدرس نويسنده مسئول: تهران ، واحد علوم دارويسى دانشعاه آزاد اسـلامى، دانشـكده داروسـازى، زهـرا

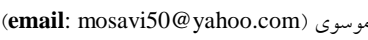
ORCID ID: 0000-0001-6524-491X تاريخ دريافت مقاله: QV/Q/1Q تاريخ بذيرش مقاله: · تاريخ دربافت مقاله 
موشها به طور تصادفى در V Vروه 9 تايى تقسيم بندى شدند:

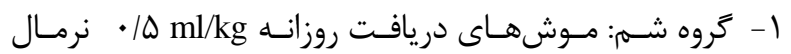
سالين r- كروه كنترل: كاواز نرمـال سـالين ml/kg هالهان • و تزريـق درون صفاقى توئين (به مدت ب ر روز)

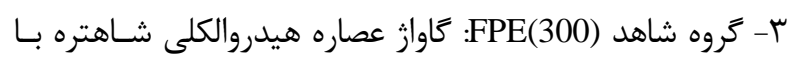

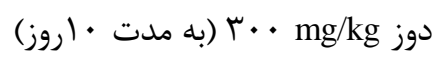

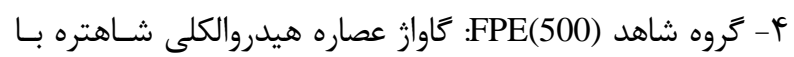
دوز

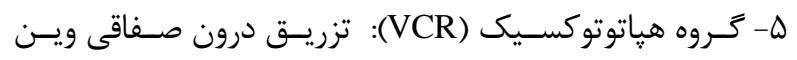
كريستين با دوز \&

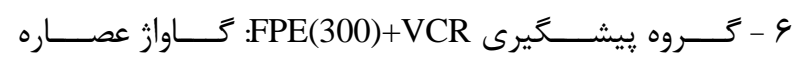

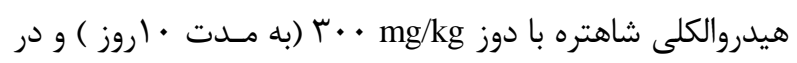

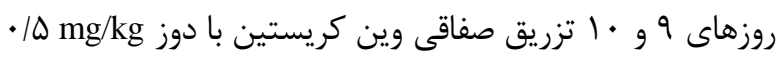

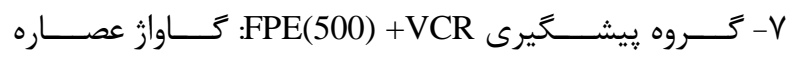

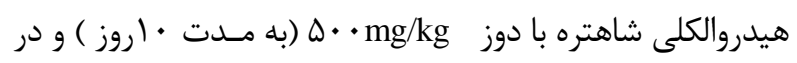

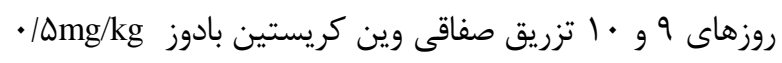

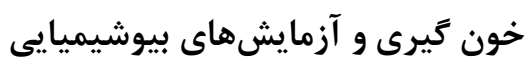

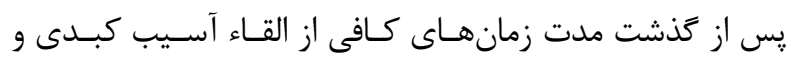

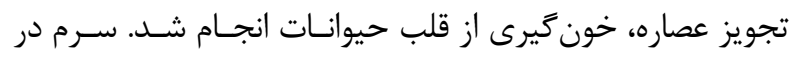

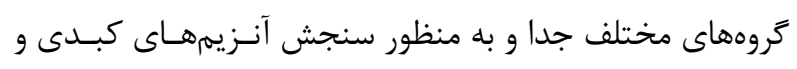

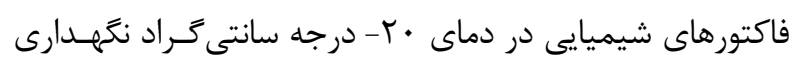

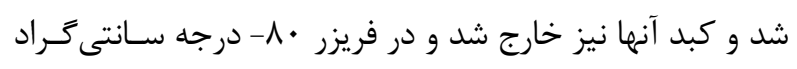

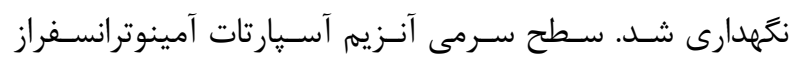

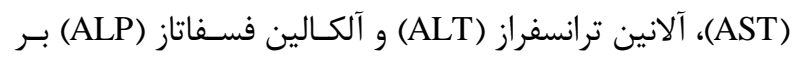

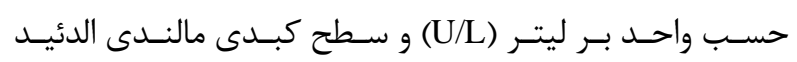
تحليhol/mg-protein)

\section{تحليل آمارى}

جهت تحليل دادهها از برنامه آمارى 6 Prism استفاده شد. داده-

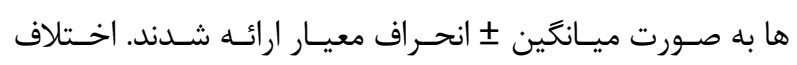

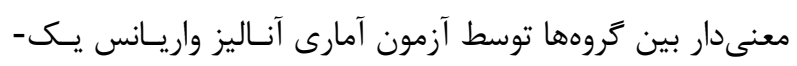

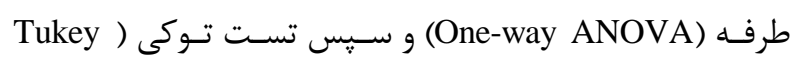
مورد ارزيابى قرار كرفت. (post test

ملاحظات اخلاقى

اين تحقيق منتج از يايان نامه دوره كارشناسى ارشد خافي إنم زهرا

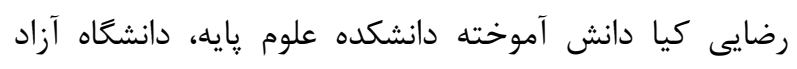

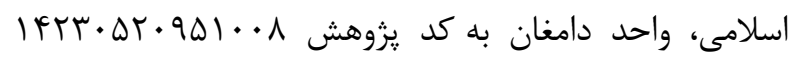

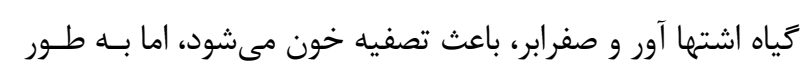

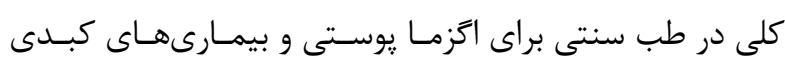

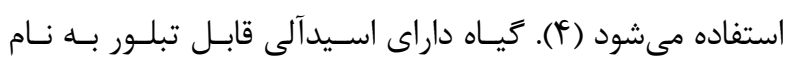

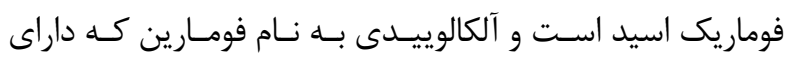

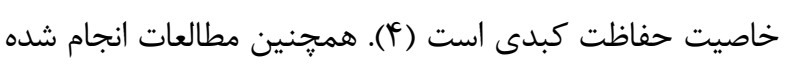

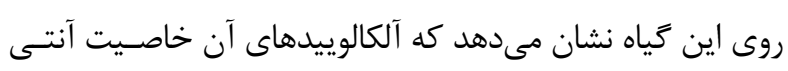

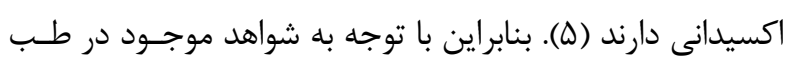

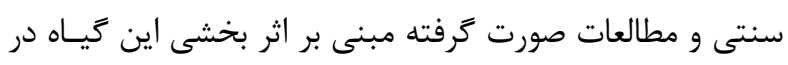

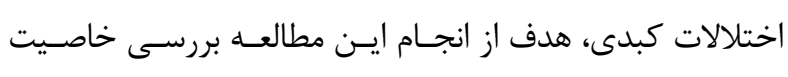

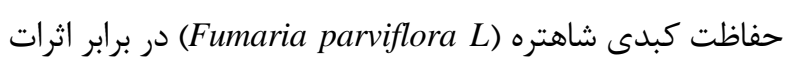
هياتوتوكسيك ايجاد شده توسط داروى وين كريستين در مـدل

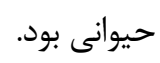

\section{مواد و روشها}

آماده سازى عصاره

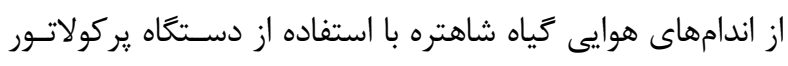

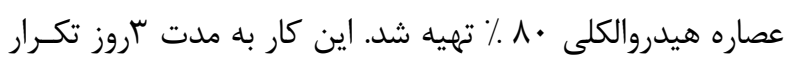

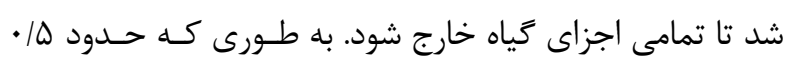

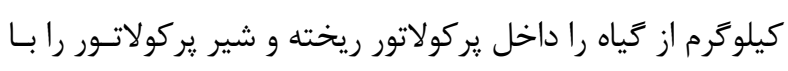

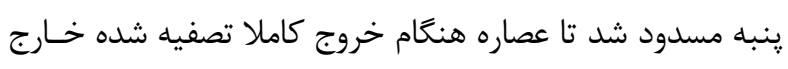

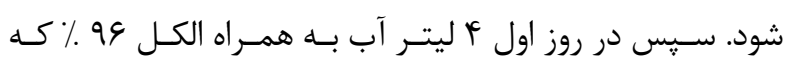

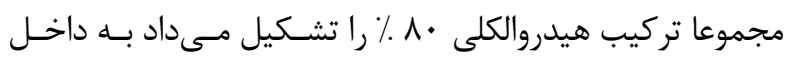

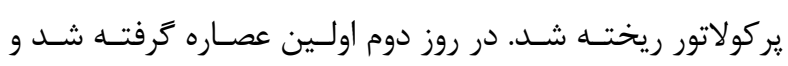

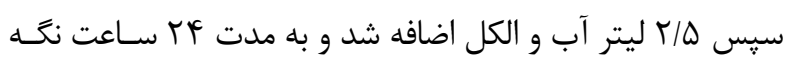

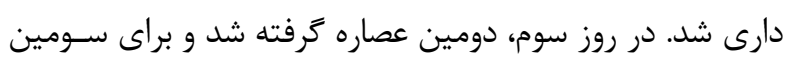

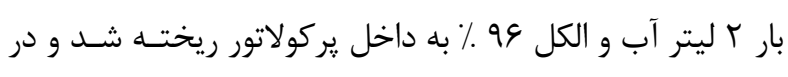

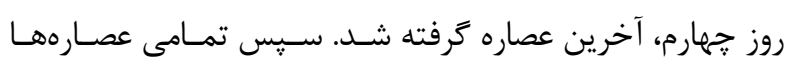

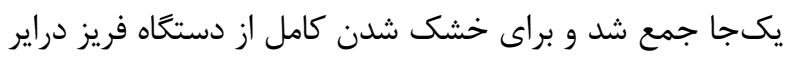

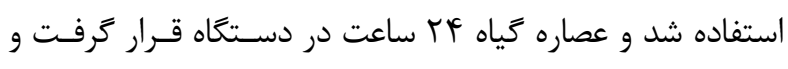

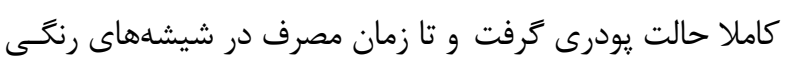
و دور از رطوبت نتحهدارى شد.

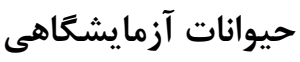

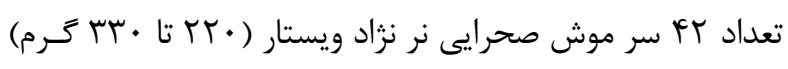

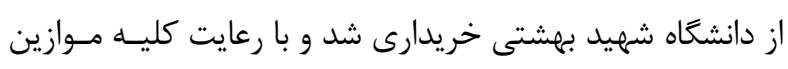

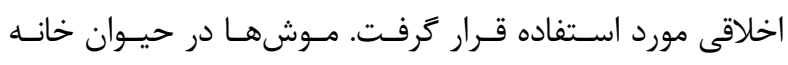

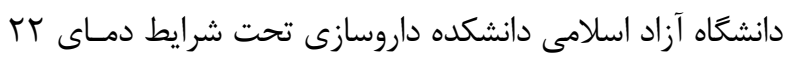

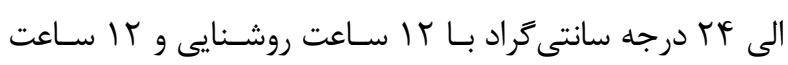
تاريكى و دسترسى كامل به آب و غذا نكَهدارى شدند. 


\section{بحث}

در سال هاى اخير كياهان دارويى به دليل داشتن خواص آنتى

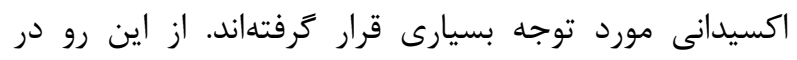

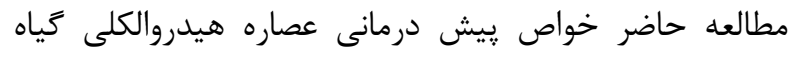

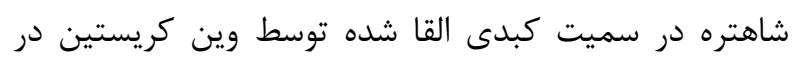

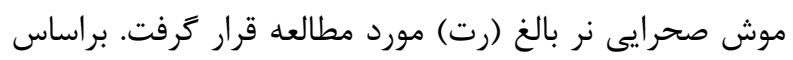

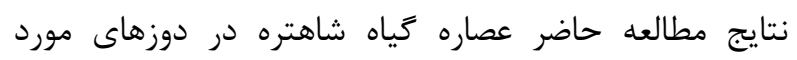

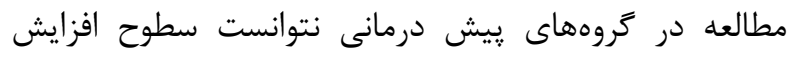

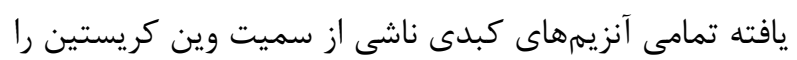

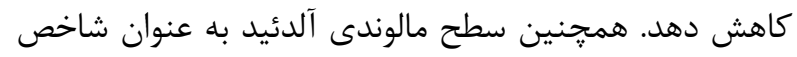

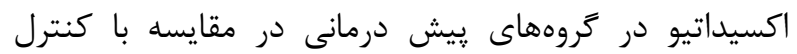

$$
\text { تغيير معنى دارى را نشان نداد. }
$$

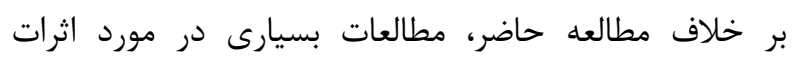

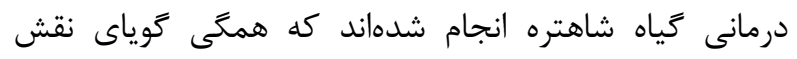

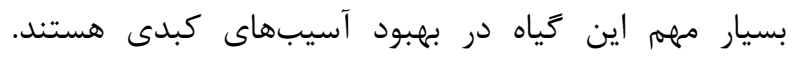

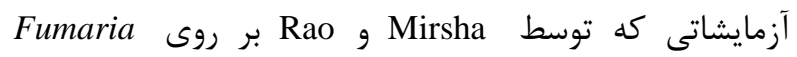
indica

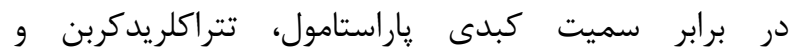

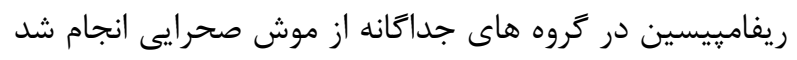

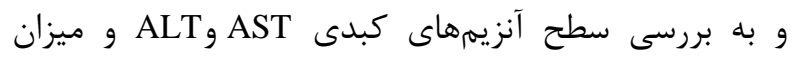
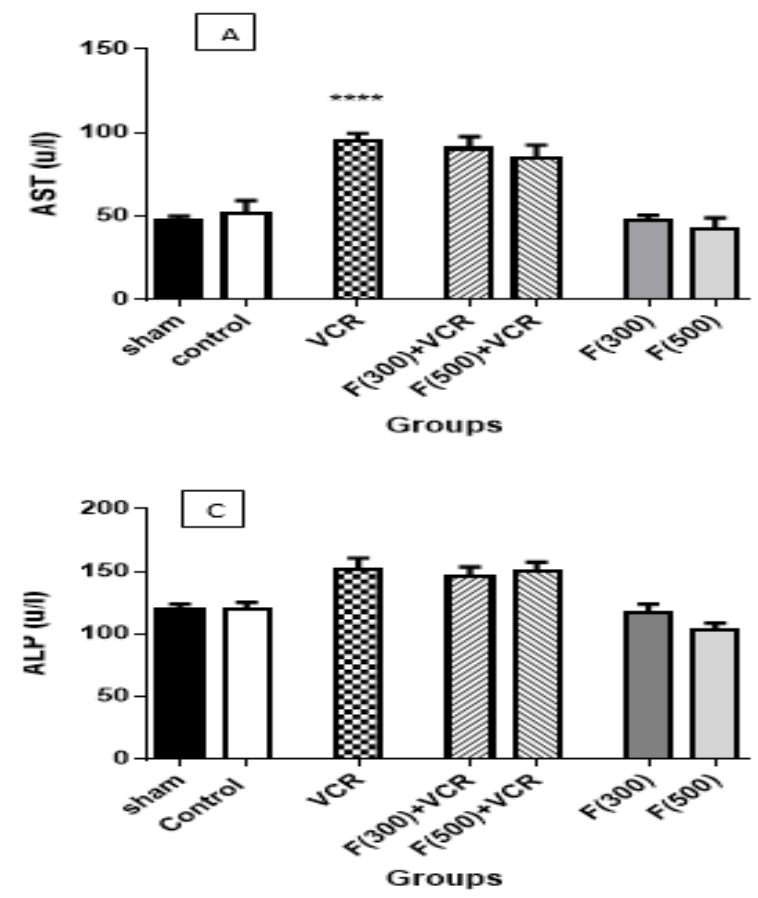

بررسى حاضر نشان داد وين كريستين با دوز مورد استفاده سبب آسيب كبدى شد. افزايش معنى دار در سطح آنزيمهاى آسيارتات ترانس آميناز و همجنين سطح آلانين آمينوترانسفراز (ALT)

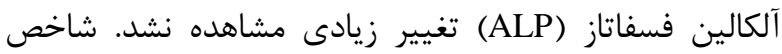

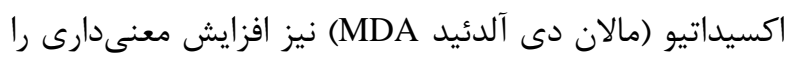

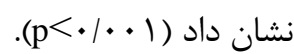

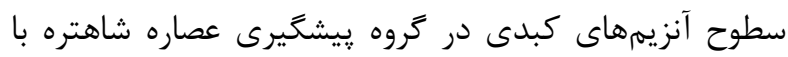

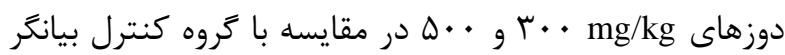

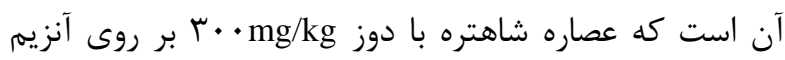

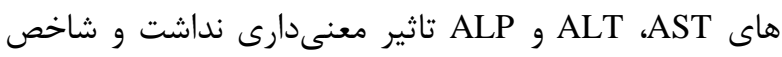

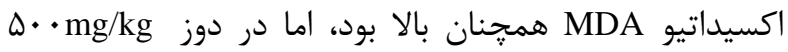
كاهش معنىدار ALT در مقايسه با كروه وين كريستين

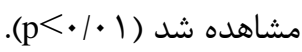

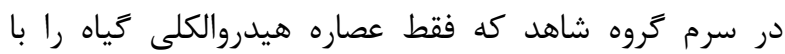

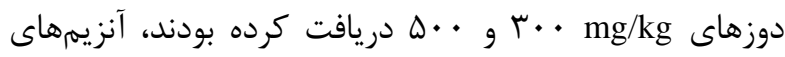
ALP و ALT،AST تفاوت קندانى با گروه كنترل نداشتند و شاخص اكسيداتيوسطح MDA در مقايسه با كروه كنتر

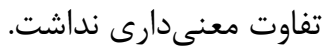
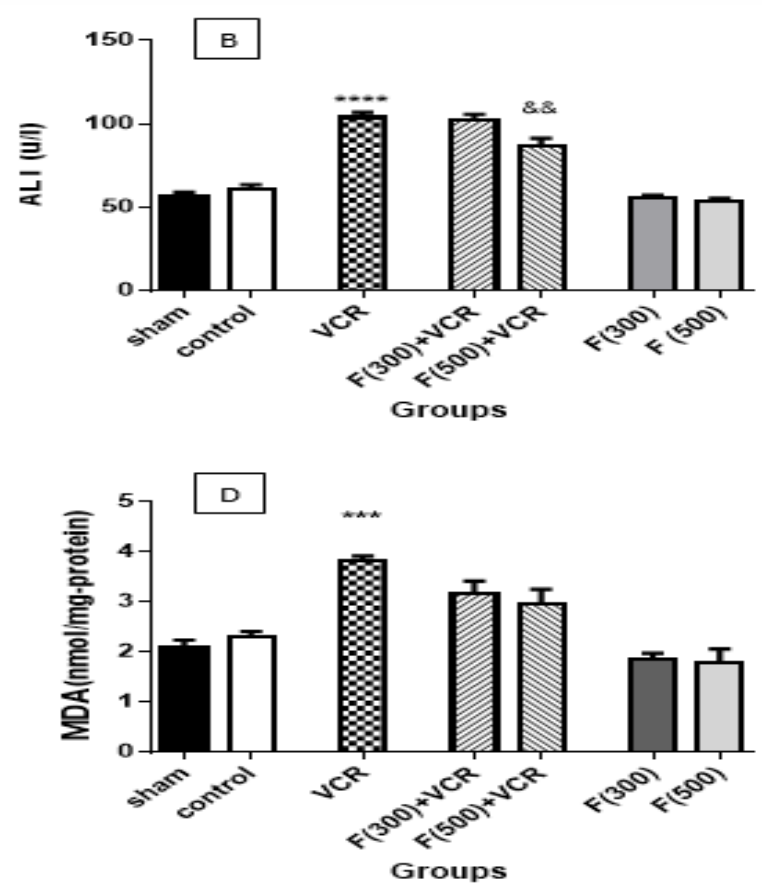

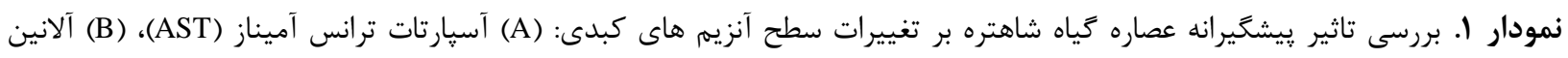

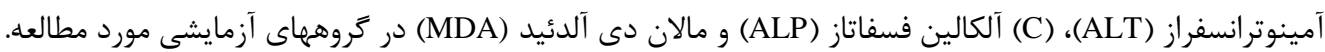

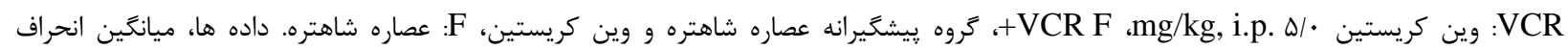

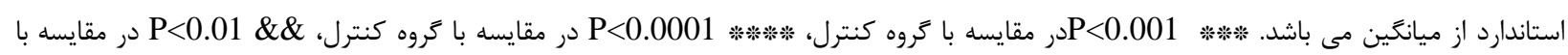


مىشوند (1 (1). همجٍنين سميت كبدى ناشى از تتراكلريدكربن به دليل شكسته شدن پييوند بين كربن - كلر و ايجاد راديكال آزاد ترى كلرومتيل عنوان شده است. اين راديكال بسيار

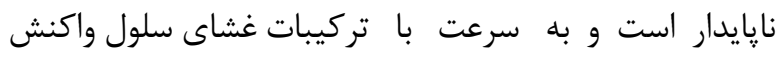
مى دهد و همجنين با اسيدهاى جرب غيراشباع باند مىشود و يا يك اتم هيدروزن را از ليييدهاى غشا جدا مى كند و توليد

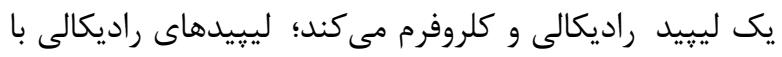
مولكول اكسيزن واكنش داده و در نتيجه فسفوليييدهاى موجود در رتيكولوم اندويلاسميك تجزيه شده و باعث آزاد شدن آنزيمها مىشوند و در نهايت اين واكنشها منجر به مرى

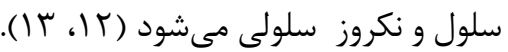
مكانيسم سميت وين كريستين، مهار عملكرد ميكروتوبولهاى

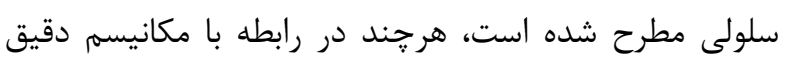
سميت كبدى اطلاعات كمى در دسترس است. Upmanyu و همكارانش در بررسى سميت كبدى ناشى از وين كريستين در

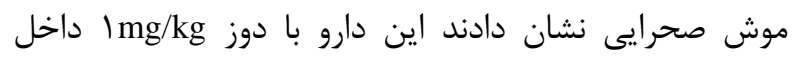
وريدى سبب كاهش وزن و افزايش سطح آنزيمهاى AST،

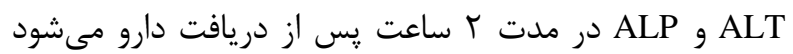
كه تا F T ساعت همجنان بالا باقى مىماند. نتايج مطالعات

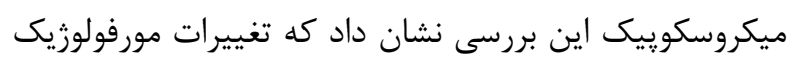
در بافت كبدى در اثر آسيب به هياتوسيتها ديده ميىشود. همجنين مشاهدات ميكروسكوٍ الكترونيك نيز نشان داد وين كريستين نه تنها سبب مهار تقسيم سلولى در كبد ميىشود، بلكه اجزاى فيبرى و الاستيك بافت كبد را هم تخريب مي كند سند

به اين ترتيب عدم كارايى عصاره گياه شاهتره در اين مطالعه مىتواند ناشى از وسعت آسيب ايجاد شده توسط وين كريستين باشد كه با افزايش دوز شاهتره و يا افزايش دوره

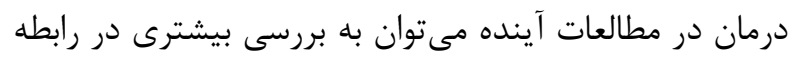
با اثرات اين زياه دست يافت. نكته مهرم ديگر حاصل از اين مطالعه، عدم ايجاد آسيب و

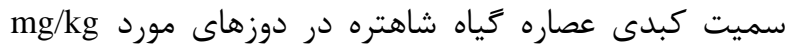

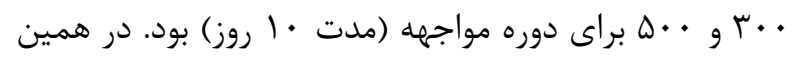
راستا مطالعهاى كه به بررسى سميت مزمن عصاره اتانلى مواجه Fumaria parviflora (كه شامل Fumaria indica مىباشد) يرداخته است، عدم سميت گياه از لحاظ يافتههاى

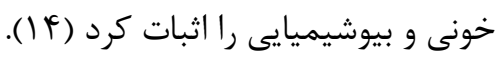
در مجموع با توجه به رشد بالاى سرطان و استفاده وين

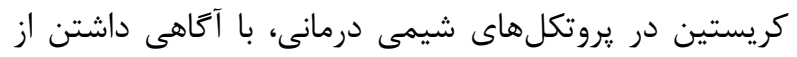

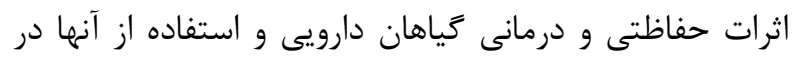

كلوتاتيون يرداخت، حاكى از اثرات محافظتى شاهتره در حد سيليمارين در اين مدلهاى سميت بود. در اين مطالعه،

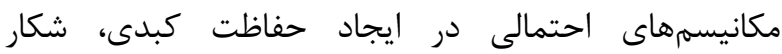

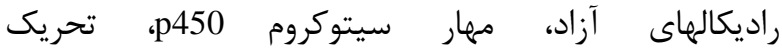
كلوكورونيداسيون، تحريك ترميم در بافت كبد و نيز مهار

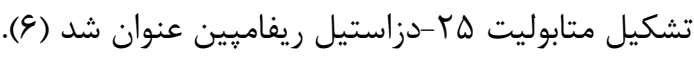

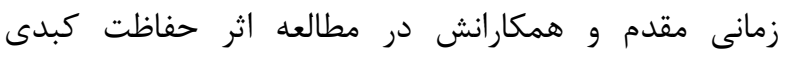
Fumaria vaillantii و Silybum marianum ناشى از استامينوفن در موش سورى نشان دادند كه زياه شاهتره اثرات حفاظتى قابل مقايسه با گياه خار مريم دارد. عصاره شاهتره و منومتيل فومارات سبب تنظيم و كاهش سطوح افزايش يافته آنزيمهاى ALP، AST، ALT، بيلى روبين، افزايش سطح كلوتاتيون كبدى و نيز كاهش آنش

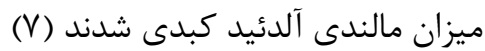

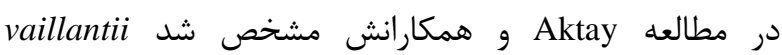
Fumaria اثرات حفاظت كبدى است، هر جند عصاره Fumaria asepalae

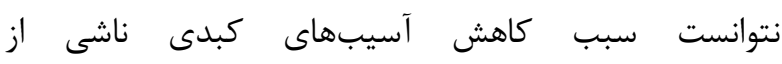
تتراكلريدكربن شود (^). غلامى و همكارانش نيز در مطالعه تاثير عصاره آبى زياه شاهتره (Fumaria officinalis)، اثرات محافظتى و درمانى در برابر آسيب كبدى ايجاد شده توسط استامينوفن در موش صحرايى را گزارش كردند (9). در مطالعه جمشيدزاده و نيك نهاد كه به بررسى اثرات Fumaria ) حفاظت كبدى عصاره هيدروالكلى زياه شاهتره (parviflora L صحرايى نر (با رزيم يك روز قبل، همزمان و يك روز بعد از

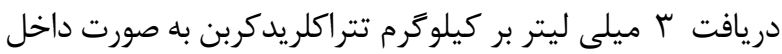

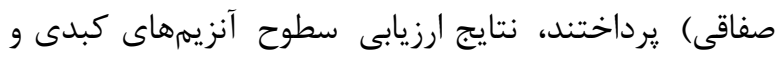
مشاهدات هيستوياتولوزيك كبد نشان داد كه شاهتره توانسته است ضايعات كبدى ايجاد شده توسط تتراكلريدكربن را در مقادير به كار رفته كاهش دهد و احتمالا اين اثر بـه واسطه لئه داشتن تركيبات آنتى اكسيدانى كياه است ( • (). يكى از دلايل اين عدم همخوانى نتايج مىتواند مرتبط با مدل سميت كبدى القاء شده با عوامل سمى مختلف باشد. براى

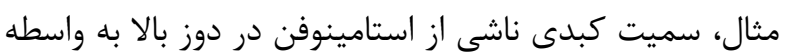

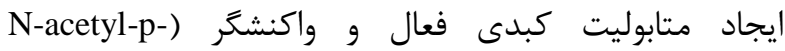
NAPQI (benzoquinoneimine گلوتاتيون كبدى شده و به ساختارهاى يروتئينى سلول متصل 


رزيم غذايى مى آتوان حفاظت عضويى مناسبى در برابر اطلاعات زياهان بومى كشور است، در جهت سلامتى مردم

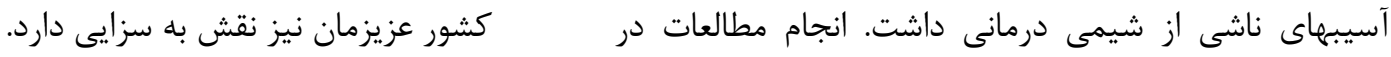

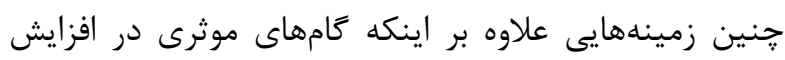

REFERENCES

1. Stanley A, Averal HI, Akbarsha M. Reproductive toxicity of vincristine in male rats. Indian J Exp Biol 1993;31:3802.

2. Upmanyu R, Dvivedi J, Saxena Y. Hepatotoxic effects of vincristine: an experimental study on albino rats. Indian J Physiol Pharmacol 2009;53:265-70.

3. Tirtash FH, Keshavarzi M, Fazeli F. Antioxidant components of Fumaria species (Papaveraceae). World Acad Sci Eng Technol 2011;50:233-6.

4. Zargari A, ed. Medicinal plants. Tehran: Tehran University Press; 1992. [In Persian]

5. Sharma UR, Prakash T, Surendra V, Rama Rao NR, Goli D. Hepatoprotective activity of Fumaria officinalis against $\mathrm{CCl}$ 4-induced liver damage in rats. Pharmacologia 2012;3:9-14.

6. Rao K, Mishra S. Antihepatotoxic activity of monomethyl fumarate isolated from Fumaria indica. J Ethnopharmacol 1998;60:207-13.

7. Zamani-Moghaddam E, Azami K, Minaei-Zangi B, Mousavi SZ, Sabzevari O. Protective activity of Fumaria vaillantii extract and monomethyl fumarate on acetaminophen induced hepatotoxicity in mice. Int $\mathrm{J}$ Pharmacol 2012;8:177-84.

8. Aktay G, Deliorman D, Ergun E, Ergun F, Yeşilada E, Cevik C. Hepatoprotective effects of Turkish folk remedies on experimental liver injury. J Ethnopharmacol 2000;73:121-9.

9. Gholami, M, Vaseie M, Erfani S, Najjarzadeh M, Hemmati M. Protective and therapeutic effects of Fumaria afficinalis aqueous extract against acetaminophen-induced chronic hepatotoxicity in rats. RJMS 2016;23:56-63. [In Parsian]

10. Jamshidzadeh A, Nikmahad H. Hepatoprotective effects of Fumaria parviflora L. on CCl4-induced hepatotoxicity. J Med Plant 2006;3:34-9.

11. Nelson SD. Molecular mechanisms of the hepatotoxicity caused by acetaminophen. Semin Liver Dis 1990;10:26778.

12. Pohl LR, George JW. Identification of dichloromethyl carbene as a metabolite of carbon tetrachloride. Biochem Biophys Res commun 1983;117:367-71.

13. Clawson GA. Mechanisms of carbon tetrachloride hepatotoxicity. Pathol Immunopatholo Res 1989;8:104-12.

14. Singh GK, Kumar V. Acute and sub-chronic toxicity study of standardized extract of Fumaria indica in rodents. J Ethnopharmacol 2011;134:992-5. 